\title{
The Effect of Ethical Leadership and Organizational Justice on Employee Engagement - The Mediating Role of Employee Trust
}

\author{
Mai Ngoc Khuong and Do Thi Thuy Dung
}

\begin{abstract}
The purpose of this research was to examine the effects of three different variables including ethical leadership, organizational justice and ethic-based contingent reward on employee trust and employee engagement in the technical companies in Vung Tau City, Vietnam. The research conceptual framework and hypotheses were constructed, based on previous theoretical and empirical studies. The primary data was collected from 312 technicians. Several statistical techniques including exploration factors analysis, multiple regressions and path analysis were used to test hypotheses of the study. The empirical results showed that ethical leadership and ethic-based contingent reward had directly effect on employee engagement. In addition, these factors and organizational justice indirectly affected employee engagement through employee trust. Consequences, the fair, ethic and reward are important role for organization. These factors can enhance the level of trust and keep the employees engaging in their jobs.
\end{abstract}

Index Terms-Organizational justice, ethical leadership, ethic-based contingent reward, employee trust and employee engagement.

\section{INTRODUCTION}

Human resource management is essential skills for managers, with having a lot of positive effect on organization. According to [1], human resource management is defined as systems of activities and strategies that focus on successfully managing employees at all levels of an organization to achieve organization goal. This management is a strategic and good instructional approach to managing people in the organization culture and environment.

In recent years, human resource management is always an important problem and low level of employee engaging towards the current jobs is new issues for today's managers. Employee engagement was defined as an "individual's involvement and satisfaction with as well as enthusiasm for work" [2].

Moreover, according to VOV news 2014 [3], labor productivity of 15 employees in Vietnam is just equal to one employee in Singapore. The survey of Nguoi Lao Dong News (2015) [4], some companies in Ho Chi Minh City did not have the Tet's (lunar new year) bonus for their employees. Low productivity and unfair reward are one of the reasons making the low level of engagement in employees. Similarity, Vung Tau City occurs with the same problem. GDP of Ba Ria Vung Tau City was generated nearly

Manuscript received April 30, 2015; revised June 5, 2015.

M. N. Khuong and D. T. T. Dung are with the School of Business, International University, VNU-HCM, Vietnam (e-mail: mnkhuong@hcmiu.edu.vn, dodung148@gmail.com).
11 percent and 27 percent of total revenue in Vietnam. As a result, many international companies operate their franchising or subsidiary company in recent years. However, employees are easily to leave the current job after the Tet's holiday or long time vacations. The low productivity, easy to leave and unfair bonus salary decrease the employee engagement in Vung Tau City.

Therefore, the objective of this study is to measure the important of employee engagement and how organizational justice, ethical leadership, ethic-based contingent reward influence the level of trust and engagement of employees in organizations. Therefore, this study provides evidence about the essential role of organizational justice, ethical leadership, ethic-based contingent reward, as well as giving constructive recommendation to managers in Vung Tau City to increase the level of engagement of employees to contribute employee's effort to the accomplishment of organization's goals.

\section{LITERATURE REVIEW}

\section{A. Ethical Leadership}

The last few years show a growing interest in the development and promotion of ethical leadership and leader effectiveness in organizations. According to [5], ethical leader as person with "right values" and "strong character", that set examples for others and withstand temptations. Ethical leadership is thought to be uniquely important because of the impact leaders may have on the conduct of the organization and ultimately on organizational performance [6], on job performance [7].

Thus, a positive relationship between ethical leadership and employees' engagement in voice behavior is found including reporting problems to management and sharing constructive ideas for work improvements [8]. Moreover, ethical leadership is the relevant behaviors that leaders can employ to demonstrate their integrity and that these behaviors are thus important antecedents to trust [9].

\section{B. Organizational Justice}

Organizational justice theory was originally derived from the similarity theory developed by Adams [10]. The theory states that fair treatment will appear if the ratio between results achieved with input he gave for an exchange is considered balanced when compared to others [11]. Moreover, further study defines that organizational justice encompasses social norms and the emergent rules in decision making and distributing to employees outcomes such as tasks, goods, services, rewards, penalties, pay, organizational 
positions, opportunities, or roles [12].

Hence, research study [13] found out that when distributions of organizational outcomes are considered to be fair, higher employee levels of trust are likely to develop and positive perception of organizational justice assists employees to feel as members of the organization which influences their organizational commitment. Moreover, organizational justice has been identified as a critical factor for employee commitment to the objectives of the organization [14], and positive perception of organizational justice assists employees to feel as members of the organization which influences their organizational commitment [15]. The more employees commit with their job, the more increasing the level of engagement of employees.

\section{Ethic-Based Contingent Reward}

A number of researchers attempted to define the domain of ethics-based leadership [16]. Ethical leadership involves role modeling and promoting ethical conduct as well as setting up ethical standards and using contingent reinforcement to manage ethical conduct [17]. Furthermore, based on the research [18], ethical leaders also use collective motivation to influence followers.

Furthermore, the contingent reward is a motivation system that is used to reward those that meet the company's identified goals. It provides positive reinforcement for a job well done. According to [19], rewards also play a central role in the social exchange approach to leadership proposed. $\mathrm{He}$ notes that "a fair exchange...involves...a climate in which a leader sees that equitable rewards are provided".

In conclusion, ethic-based contingent reward is an important factor for organization. Ethic-based contingent reward will increase and enhance the trust for employer and keeping employee engagement with the jobs [8], [20]-[22].

\section{Employee Trust}

Trust-developing strategies are important factors in in successful companies. According to the Webster's Dictionary 1985 edition, the definition of trust is confidence; implicit faith; moral responsibility; to have implicit faith in; to be confident or confide in. Trust is considered one of the most influential variables on organizational performance [23]. Therefore, [24] trust is a prerequisite to engagement.

\section{E. Employee Engagement}

The first concept of employee engagement appears in an Academy of Management Journal article, "Psychological Conditions of Personal Engagement and Disengagement at Work" [25], the simultaneous employment and expression of a person's 'preferred self' in task behaviors that promote connections to work and to others, personal presence, and active full role performances". Throughout many years, the different approaches defining the employee engagement construct partly from differing philosophies and from which employee engagement is perceived. According to [26], defining employee engagement is "a distinct and unique construct consisting of cognitive, emotional, and behavioral components, etc., associated with individual role performance". Moreover, engaged employees have consistently shown to be more productive, profitable, safer, healthier, and less likely to leave their employer [27].
Moreover, the positive effect of employee engagement has been proven by many researchers. [28] found that engagement in meaningful work can lead to perceived benefits from the work. Moreover, [29], engagement as a mediating variable for the relationship between the six work conditions and work various outcomes and like burnout, should be related to outcomes such as increased withdrawal, lower performance, job satisfaction, and commitment.

\section{F. The Proposed Hypothetical Model}

Fig. 1 illustrates the hypothetical causal model of this study which proves the direct and indirect influence of ethical leadership, organizational justice and ethic-based contingent reward on employee trust/employee engagement and the casual relationship among those factors.

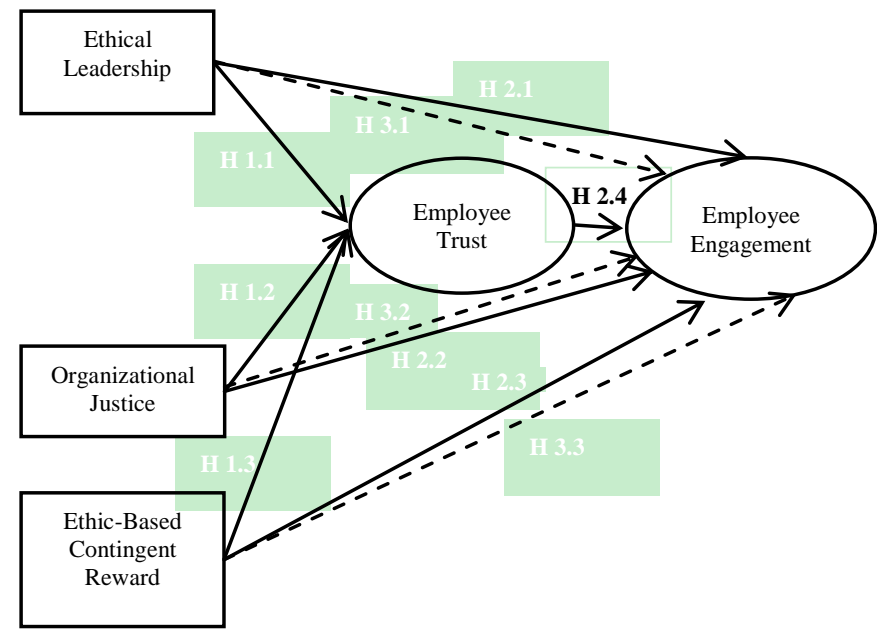

Fig. 1. The proposed hypothetical model.

$\mathrm{H}_{1.1}$ : Ethical leadership positively affects employee trust.

$\mathrm{H}_{1.2}$ : Organizational justice positively affects employee trust.

$\mathrm{H}_{1.3}$ : Ethic-based contingent reward positively affects employee trust.

$\mathrm{H}_{2.1}$ : Ethical leadership positively affects employee engagement.

$\mathrm{H}_{2.2}$ : Organizational justice positively affects employee engagement.

$\mathrm{H}_{2.3}$ : Ethic-based contingent reward positively affects employee engagement.

$\mathrm{H}_{2.4}$ : Employee trust positively affects employee engagement.

$\mathrm{H}_{3.1}$ : The effect of ethical leadership on employee engagement is mediated by employee trust.

$\mathrm{H}_{3.2}$ : The effect of organizational justice on employee engagement is mediated by employee trust.

$\mathrm{H}_{3.3}$ : The effect of ethic-based contingent reward on employee engagement is mediated by employee trust.

\section{METHODOLOGY}

\section{A. Questionnaire Design and Data Collection}

In this study, quantitative approach was applied with questionnaire survey. Most measured items in the questionnaire were use the 5 point Likert scale with (1=Strongly disagree, $2=$ Disagree, $3=$ Neutral, 4=Agree, and $5=$ Strongly agree). The structured questionnaires were 
conveniently and directly delivered to 312 technicians of technical companies in Vung Tau City.

\section{B. Data Analysis}

Variables and data were coded and a SPSS (Statistical Package for the Social Science) program was used for data analysis. First, Exploratory Factor Analysis (EFA) and Reliability Test were applied to ensure the validity and the reliability of variables. After this step, Multiple Regression and Path Analysis were used to explore the relationships and test the hypotheses of the study.

For this study, exploratory factor analysis (EFA) was applied twice, the first was for independent variables and the second was for dependent variables. The KMO for independent variables was .910 and the KMO for dependent variables was .859 which was greater than minimum value of .6 (according to [30]). In addition, the sig of Bartlett's Test of both independent and dependent variables was .000 , indicating sufficient correlation between the variables.

The Table I below summarized the reliability of factors in independent variables by based on number of Cronbach Alpha.

TABLE I: SUMMARY OF INDEPENDENT VARIABLES

\begin{tabular}{lcc}
\hline \multicolumn{1}{c}{ Factors } & $\begin{array}{c}\text { No. of } \\
\text { Items }\end{array}$ & $\begin{array}{c}\text { Cronbach } \\
\text { Alpha }\end{array}$ \\
\hline Factor 1: Organizational Justice & 16 & .937 \\
Factor 2: Ethical Leadership & 8 & .860 \\
Factor 3: Ethic-Based Contingent Reward & 4 & .697 \\
\hline
\end{tabular}

For the group of independent variables, 28 items of organizational justice, ethical leadership and ethic-based contingent reward were highly loaded together in three different factors. All of the factor loadings of remained items were above .5 ranging from .517 to .848 . In addition, the Cronbach's alpha coefficient of three components were from .697 to .937 (According [31], the Cronbach's coefficient alpha value above .60 was considered acceptable).

TABLE II: SUMMARY OF DEPENDENT VARIABLES

\begin{tabular}{lcc}
\hline \hline \multicolumn{1}{c}{ Factors } & $\begin{array}{c}\text { No. of } \\
\text { Items }\end{array}$ & $\begin{array}{c}\text { Cronbach } \\
\text { Alpha }\end{array}$ \\
\hline Factor 1: Employee Engagement & 6 & .819 \\
Factor 2: Employee Trust & 5 & .780 \\
\hline
\end{tabular}

The result of the second EFA showed that 11 items of dependent variables were grouped into two components including employee engagement and employee trust with factor loading ranging from .611 to .818. The Cronbach's alpha values were .819 for employee engagement and .780 for employee trust as shown in the Table II.

\section{RESEARCH FINDINGS}

\section{A. Profile of the Sample}

Demographics information was illustrated and analyzed by SPSS Program in Table III below.

\section{B. Factors Affecting Employee Trust and Employee Engagement}

Table IV indicates that there were positive relationships between the dependent variable of EMENGA and the independent variables of ORGJUSTI $(r=.223, p<.05)$,
ETHLEAD ( $r=.366, p<.05)$, ETBACORE $(r=.808, p<.05)$, and EMTRUST $(r=.534, p<.05)$. The means that the higher level of organizational justice, ethical leadership behavior, ethic-based contingent reward would lead to the higher level of employee trust and employee job engagement.

\begin{tabular}{|c|c|c|c|}
\hline & & Frequency & Percent \\
\hline \multirow{3}{*}{ Gender } & Male & 135 & 43.3 \\
\hline & Female & 177 & 56.7 \\
\hline & Total & 312 & 100 \\
\hline \multirow{3}{*}{$\begin{array}{l}\text { Marital } \\
\text { Status }\end{array}$} & Single & 124 & 39.7 \\
\hline & Married & 188 & 60.3 \\
\hline & Total & 312 & 100 \\
\hline \multirow{6}{*}{ Age } & From 18 to 25 years old & 43 & 13.8 \\
\hline & From 25 to 35 years old & 133 & 42.6 \\
\hline & From 35 to 45 years old & 85 & 27.2 \\
\hline & From 45 to 55 years old & 47 & 15.1 \\
\hline & Over 55 years old & 4 & 1.3 \\
\hline & Total & 312 & 100 \\
\hline \multirow{6}{*}{ Seniority } & Under 1 year & 10 & 3.2 \\
\hline & From 1 to 4 years & 57 & 18.3 \\
\hline & From 4 to 7 years & 121 & 38.8 \\
\hline & From 7 to 10 years & 65 & 20.8 \\
\hline & Over 10 years & 59 & 18.9 \\
\hline & Total & 312 & 100 \\
\hline \multirow{6}{*}{ Education } & High school & 0 & 0 \\
\hline & Vocational Secondary & 22 & 7.1 \\
\hline & College & 70 & 22.4 \\
\hline & University & 176 & 56.4 \\
\hline & Master & 44 & 14.1 \\
\hline & Total & 312 & 100 \\
\hline \multirow{4}{*}{ Position } & Employee & 253 & 81.1 \\
\hline & Supervisor & 42 & 13.5 \\
\hline & Manager & 17 & 5.4 \\
\hline & Total & 312 & 100 \\
\hline
\end{tabular}

TABLE IV: CORRELATIONS BETWEEN VARIABLES OF THE RESEARCH MODEL

\begin{tabular}{|c|c|c|c|c|}
\hline & EMENGA & 1 & 2 & 3 \\
\hline 1.ORGJUSTI & $.223^{*}$ & & & \\
\hline 2.ETLEAD & $.366^{*}$ & $.070 *$ & & \\
\hline 3.ETBACORE & $.808^{*}$ & $.078 *$ & $.225^{*}$ & \\
\hline 4.EMTRUST & $.534 *$ & $.587 *$ & $.581 *$ & $.368^{*}$ \\
\hline Mean & 3.62 & 3.52 & 3.57 & 3.51 \\
\hline Std. Deviation & .539 & .655 & .719 & .746 \\
\hline
\end{tabular}

*. Correlation is significant at the .05 level.

In order to test $\mathrm{H}_{1.1}, \mathrm{H}_{1.2}$, and $\mathrm{H}_{1.3}$, the first multiple regression analysis was conducted to test the effects of the independent variables of ORGJUSTI, ETLEAD, and ETBACORE on the dependent variable of EMTRUST. As the results shown in table V, ORGJUSTI $(B=.430, p<.05)$ had strongest impact on EMTRUST, ranked second was ETLEAD $(B=.362, p<.05)$ and the third was ETBACORE $(\beta=.152, p<.05)$. This means that every 1 standard deviation change in organizational justice, or ethical leadership, or ethic-based contingent reward would lead to an increase in employee trust of .430 , or .362 , or .152 , respectively, while other variables were controlled for.

To conclude, three independent variables (organizational justice, ethical leadership, ethic-based contingent reward) had positive and direct effects on employee trust. Therefore, the hypothesis $\mathrm{H}_{1.1}, \mathrm{H}_{1.2}, \mathrm{H}_{1.3}$ was accepted.

Table VI illustrates the results of the second multiple regression analysis between the dependent variable of EMENGA and ORGJUSTI, ETLEAD, ETBACORE, and EMTRUST. ETBACORE $(B=.517, p<.05)$ was the most powerful predictor of EMENGA, then EMTRUST $(B=.192$, 
$p<.05)$, and ETLEAD $(B=.069, p<.05)$. This means that every 1 standard deviation change in ethic-based contingent reward, or ethical leadership, or employee trust would lead to an increase in employee engagement of .517, or .192, or .069, respectively, while other variables were controlled for. ORGJUSTI did not affect employee engagement.

\begin{tabular}{lccc}
\multicolumn{4}{c}{ TABLE V: EFFECT COEFFICIENTS BETWEEN IVS AND EMTRUST } \\
anstandardized & & \\
& & & \\
& Coefficients & t-value & Sig. \\
ORGJUSTI & .582 & 4.357 & .000 \\
ETLEAD & .430 & 16.589 & .000 \\
ETBACORE & .362 & 14.967 & .000 \\
& .152 & 6.503 & .000 \\
\hline
\end{tabular}

Note: Dependent Variable: EMTRUST: Employee Trust

Predictors: ORGJUSTI, ETLEAD, ETBACORE

ANOVA: $F(3,308)=219.485$, Sig. $=000, p<.05$

Model summary: $R^{2}=.681$.

TABLE VI: EFFECT COEFFICIENTS BETWEEN IVS AND ENGAGEMENT

\begin{tabular}{lccc}
\hline \hline \multicolumn{1}{c}{ Variables } & $\begin{array}{c}\text { Unstandardized } \\
\text { Coefficients }\end{array}$ & t-value & Sig. \\
\hline & .657 & 4.980 & .000 \\
1.ORGJUSTI & .042 & 1.219 & .224 \\
2.ETLEAD & .069 & 2.273 & .024 \\
3.ETBACORE & .517 & 21.687 & .000 \\
4.EMTRUST & .192 & 3.520 & .000 \\
\hline
\end{tabular}

Note: Dependent Variable: EMENGA: Employee Engagement

Predictors: ORGJUSTI, ETLEAD, ETBACORE, EMTRUST

ANOVA: $F(4,307)=200.159$, Sig. $=000, p<.05$.

Model summary: $R^{2}=.723$.

To summarize, ethical leadership, ethic-based contingent reward and employee trust directly affected employee engagement. Thus, the hypothesis $\mathrm{H}_{2.1}, \mathrm{H}_{2.3}, \mathrm{H}_{2.4}$ was accepted and hypothesis $\mathrm{H}_{2.2}$ was rejected.

\section{Indirect Effects of Employee Engagement}

In order to test the effects of variables, casual steps approach/path analysis was used that is the most widely-used method [32]. This approach requires the researcher to estimate each of the paths in the model and then ascertain whether a variable functions as a mediator by seeing if certain statistical criteria are met [33]. Furthermore, path analysis was applies to provide estimates of the magnitude and significance of hypothesized causal connections between sets of variables. Path analysis was a straightforward extension of multiple regressions.

As the results, the employee trust was directly affected by ethical leadership $(B=.362, p<.05)$, organizational justice $(B=.430, p<.05)$ and ethic-based contingent reward $(B=.152$, $p<.05)$. Furthermore, employee engagement was also affected directly by ethical leadership and ethic-based contingent reward with $(B=.069, p<.05)$ and $(B=.517$, $p<.05)$, respectively. The employee trust directly affected employee engagement with $(B=.192, p<.05)$. Hence, through the mediate variable (employee trust), ethical leadership, organizational justice and ethic-based contingent reward had indirectly effect on employee engagement.

\section{Significance of the Indirect Effects}

Table VII indicates to total results of indirect effect among variables. This table showed the results of bootstrapping method. Bootstrapping is already implemented in some popular programs such as SPSS, SAS, and R to bootstrap indirect effects (e.g. [34]). Moreover, bootstrapping is one of the more valid and powerful methods for testing intervening variable effects [35], [36].

Moreover, if zero does not occur between the LL and the UL, then we can conclude that, with $95 \%$ confidence, the mediation or indirect effect is significant or vice versa [37].

As can be seen from table VII, the number of LL and UL of ETLEAD was .0368 and .1038 and the ORGJUSTI had .0435 (LL) and .1231 (UL) and ETBACORE had .0145 (LL) and .0456 (UL). Since zero did not appear in the $95 \%$ confidence, therefore, the indirect effect of ethical leadership, organizational justice and ethic-based contingent reward on employee engagement through employee trust was true and the hypothesis $\mathrm{H}_{3.1}, \mathrm{H}_{3.2}, \mathrm{H}_{3.3}$ was accepted.

TABLE VII: DIRECT, INDIRECT AND TOTAL EFFECTS

\begin{tabular}{llllll}
\hline \hline Variables & Direct & Indirect & Total & LL & UL \\
\hline ETLEAD & .069 & .013 & .082 & .0368 & .1038 \\
ORGJUSTI & $\ldots$. & .083 & .083 & .0435 & .1231 \\
ETBACORE & .517 & .029 & .546 & .0145 & .0456 \\
EMTRUST & .192 & $\ldots$. & .192 & & \\
\hline TOTAL & .778 & .125 & .903 & & \\
\hline \hline
\end{tabular}

\section{E. The Causal Effects of Employee Engagement}

The direct and indirect effect of independent variables and mediate variable on dependent variable was summarized in table VII. Based on the unstandardized coefficient, the ethic-based contingent reward $(B=.546)$ had strongest influence on employee engagement. Moreover, ethical leadership and organizational justice had the same effect on employee engagement which is $B=.082$ and $B=.083$, respectively. Finally, total effect on these factors on employee engagement is .903 , direct effect accounts for around 88 percent and the percentage of indirect effect is nearly 11 percent.

Fig. 2 below indicated the results of hypothesis testing and the unstandardized coefficient beta of each effect.

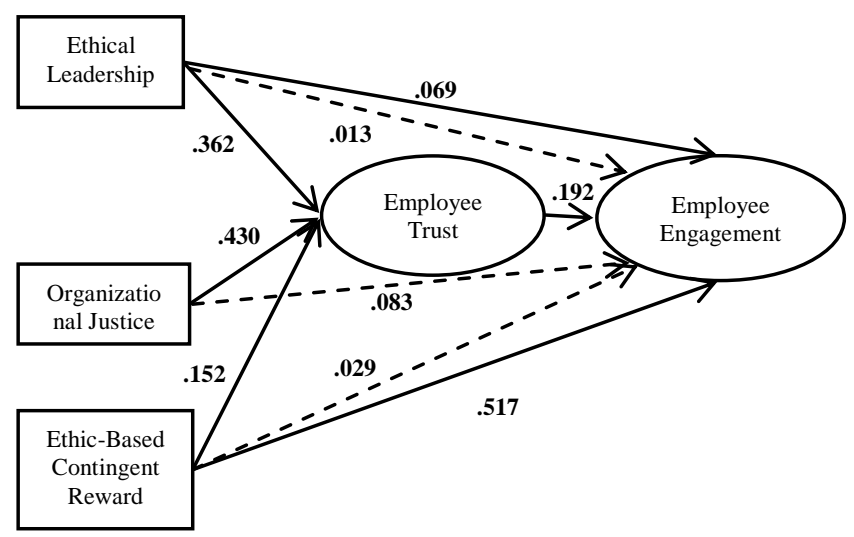

Fig. 2. Path coefficients of hypothesis testing.

Note: All coefficients in the model were significant at the .05 level.

\section{DISCUSSIONS AND RECOMMENDATIONS}

\section{A. Discussions}

This study provided the empirical evidence for supporting the proposed model which explained the factors affecting the engagement of employees in Vung Tau City, Vietnam. Based on the statistical results, ethical leadership, organizational justice and ethic-based contingent reward had effects on 
employee trust. Moreover, these factors also impacted on employee engagement through employee trust. Therefore, when employees believe that they work with ethical leader and receive the worthy reward with their effort, and can work in the justice organization; this means that it will increase the level of trust and engagement to the employer and organization.

Based on the previous research [9], [13], [20], [21], and statistical data of this study, ethical leadership; organizational justice and ethic-based contingent reward played an essential role and impact directly effect on employee trust.

Furthermore, based on the findings [8], [22], and relying on the statistical data in this study, ethical leadership and ethic-based contingent reward affected directly on employee engagement. In addition, in the findings of [14], [15], they believed that organizational justice had directly effect on employee engagement, however, in this study; employee engagement was not directly affected by organizational justice.

To summary, the table VIII below indicates the empirical results of relationship between ethical leadership, organizational justice, ethic-based contingent reward, and employee trust and employee engagement. All research hypotheses were accepted; except for organizational justice, this factor did not directly affect employee engagement.

TABLE VIII: RESULTS OF THE RESEARCH'S HYPOTHESES

\begin{tabular}{lccc}
\hline \multicolumn{1}{c}{ Hypotheses } & B & Sig. & Results \\
\hline H1.1: ETLEAD $\rightarrow$ EMTRUST & .362 & .000 & Accepted \\
H1.2: ORGJUSTI $\rightarrow$ EMTRUST & .430 & .000 & Accepted \\
H1.3: ETBACORE $\rightarrow$ EMTRUST & .152 & .000 & Accepted \\
H2.1: ETLEAD $\rightarrow$ EMENGA & .069 & .024 & Accepted \\
H2.2: ORGJUSTI $\rightarrow$ EMENGA & .042 & .224 & Rejected \\
H2.3: ETBACORE $\rightarrow$ EMENGA & .517 & .000 & Accepted \\
H2.4: EMTRUST $\rightarrow$ EMENGA & .192 & .000 & Accepted \\
H3.1: ETLEAD $\rightarrow$ EMTRUST $\rightarrow$ EMENGA & .013 & .000 & Accepted \\
H3.2: ORGJUSTI $\rightarrow$ EMTRUST $\rightarrow$ EMENGA & .083 & .000 & Accepted \\
H3.3: ETBACORE $\rightarrow$ EMTRUST $\rightarrow$ EMENGA & .029 & .000 & Accepted \\
\hline \hline
\end{tabular}

\section{B. Recommendations}

This section proposes some constructive recommendations for technical companies in Vung Tau City in specific and in Vietnam in general.

Based on the statistical data, this finding proved the positively significant correlations between ethical leadership, organizational justice, ethic-based contingent reward and employee trust and employee engagement. This finding also provides the important role of those factors with the level of engagement of employees in organizations. Thus, managers should know that the fairness, ethic and reward are the one of the most important expectation of employees with company. Achieving these expectations, employees will enhance their effort to improving the productivity of the job. Therefore, managers should pay attention and create those factors in organization.

Firstly, building justice to organizational system is very important. The justice should begin from recruit employees. Selecting process should be equal; the talented candidates should have a change to work in organization. No selecting employees base on the relationship with managers or money. Moreover, when deciding the job and work load for each employee, it should be well balanced. Manager might know which job is suitable for each employee, in order to achieve the highest results. Sometimes, managers should listen to the supporting and opinion from employees to improve the decisions. Furthermore, equal opportunity for promoting and paying is important for employees. They will have more enthusiasm to work. Besides that, company and manager usually create the reward program for good employees. Thus, creating the fairness plays essential role, when company creates the justice from the recruiting employees to though activities, the employees believe more and work loyalty with company which increase a lot of good results for company.

Secondly, besides the justice in company, the leader has ethical behavior is also important. Company should encourage the ethical leadership in the organization. Since the company already exist the justice environment, thus company should select the employees and employers who have ethical personal traits to build more ethical and fair environment in company. These components will enhance the trust among employees; they are more commitment with their job. Hence, the employee engagement will increase and improve.

Finally, reward is the significant material in the company. Reward is similar a tool to help employees reliant with company. Furthermore, this study already proved the high relationship of ethic-based contingent reward on the employee engagement, this factor is very important for employees. Ethic in delivering the reward increases more the belief of companies and also increases more the level of engagement.

\section{CONCLUSION}

All the purposes of this study were to testing and finding the relationship of ethical leadership, organizational justice and employee trust, employee engagement, examining the effects of three independent variables, mediate variable on employee engagement and exploring the effects of three independent variables on employee engagement through employee trust. Finally, giving some constructive recommendations is to helping the managers improving the engagement in technical companies.

Furthermore, some statistical techniques were used to explain and test all research hypotheses. Therefore, this study theoretically contributed a more comprehensive model of direct effects of ethical leadership, organizational justice and ethic-based contingent reward on employee trust/employee engagement and the indirect effects of these three independent variables on employee engagement through employee trust to develop and confirm the theoretical background of management.

\section{REFERENCES}

[1] L. Byars and L. Rue, Human Resource Management, $8^{\text {th }}$ ed. New York, NY: McGraw-Hill/Irwin, 2006, pp. 371-383.

[2] J. K. Harter, F. L. Schmidt, and T. L. Hayes, "Business-unit-level relationship between employee satisfaction employee engagement, and business outcomes: A meta-analysis," Journal of Applied Psychology, vol. 87, pp. 268-279, 2002

[3] P. Thoa. (October 2014). Low productivity in Vietnam and why. [Online]. Available: http://vov.vn/kinh-te/nang-suat-lao-dong-o-viet-nam-thap-vi-sao-3555 37.vov

[4] H. Dao. (January 2015). Tet bonus is ethical. [Online]. Available: http://nld.com.vn/thoi-su-trong-nuoc/thuong-tet-la-dao-ly-201501312 22119019.htm 
[5] R. E. Freeman and L. Stewart, "Developing ethical leadership," A Bridge Paper of Business Roundtable Institute for Corporate Ethics, 2006.

[6] E. Aronson, "Integrating leadership styles and ethical perspectives," Canadian Journal of Administrative Sciences, vol. 18, pp. 244-256, 2001.

[7] R. Khuntia and D. Suar, "A scale to assess ethical leadership of indian private and public sector managers," Journal of Business Ethics, vol. 49, pp. 13-26, 2004.

[8] F. O. Walumbwa and J. M. Schaubroeck, "Leader personality traits and employee voice behavior: Mediating roles of ethical leadership and work group psychological safety," Journal of Applied Psychology, vol. 94, pp. 1275-1286, 2009.

[9] L. K. Treviño, L. P. Hartman, and M. E. Brown, "Moral person and moral manager: How executives develop a reputation for ethical leadership," California Management Review, vol. 42, pp. 128-142, 2000.

[10] J. S. Adams, "Inequity in social exchange," in Advances in Experimental Social Psychology, L. Berkowitz, Ed. New York: Academic Press, 1965, ch. 2, pp. 267-299.

[11] T. M. Welbourne, D. B. Balkin, and L. R. Gomez-Mejia, "Gainsharing and mutual monitoring: A combined agency-organizational justice interpretation," Academy of Management Journal, vol. 38, pp. $881-899,1995$

[12] R. Folger and R. Cropanzano, Organizational Justice and Human Resource Management, CA: Sage, Thousand Oaks, 1998.

[13] R, Pilla, E. S. Williams, and J. J. Tan, "Are the scales tipped in favour of procedural or distributive justice? An investigation of the USA, India, Germany and Hong Kong (China)," The International Journal of Conflict Management, vol. 12, pp. 312-32, 2001.

[14] K. T. Dirk and D. L. Ferrin, "Trust in leadership: Meta-analytic findings and implications for research and practice," Journal of Applied Psychology, vol. 87, pp. 611-28, 2002.

[15] K. Y1lmaz and M. Tasdan, "Organizational citizenship and organizational justice in Turkish primary schools," Journal of Educational Administration, vol. 47, pp. 108-126, 2008.

[16] B. M. Bass and P. Steidlmeier, "Ethics, character, and authentic transformational leadership behavior," Leadership Quarterly, vol. 10, pp. 181-218, 1999.

[17] M. E. Brown, L. K. Trevino, and D. A. Harrison, "Ethical leadership: A social learning perspective for construct development and testing," Organizational Behaviour and Human Decision Processes, vol. 97, pp. 117-134, 2005

[18] C. J. Resick, P. J. Hanges, M. W. Dickson, and J. K. Mitchelson, "A cross-cultural examination of the endorsement of ethical leadership,' Journal of Business Ethics, vol. 63, pp. 345-359, 2006.

[19] E. P. Hollander, Leadership Dynamics: A Practical Guide to Effective Relationships, New York: Free Press, 1978.

[20] L. K. Trevino, M. Brown, and L. P. Hartman, "A qualitative investigation of perceived executive ethical leadership: Perceptions from inside and outside the executive suite," Human Relations, vol. 56 , pp. 5-37, 2003.

[21] J. K. Rempel, J. G. Holmes, and M. D. Zanna, "Trust in close relationships," Journal of Personality and Social Psychology, vol. 49 pp. 95-112, 1985.

[22] W. E. Scott, "Jr. Leadership: A functional analysis," in Leadership: The Cutting edge, J. E. Hunt and L. L. Larson, Eds. Carbondale, 111: Southern Illinois University Press, 1977, pp. 84-93.

[23] P. D. Villiers and G. Kooy, "contribution of worker participation to increase the efficiency of firms," S. Afr. J. Bus. Manage., vol. 35, pp. 23-29, 2004

[24] W. Macey and B. Schneider, "The meaning of employee engagement," Industrial and Organizational Psychology, 2008, ch.1, pp. 3-30.
[25] W. A. Kahn, "Psychological conditions of personal engagement and disengagement at work," Academy of Management Journal, vol. 33, pp. 692-724, 1990.

[26] A. M. Saks, "Antecedents and consequences of employee engagement," Journal of Managerial Psychology, vol. 21, pp 600-619, 2006.

[27] R. Wagner and J. K. Harter, 12: The Great Elements of Managing, Washington, DC: The Gallup Organization, 2006.

[28] T. W. Britt, A. B. Adler, and P. T. Bartone, "Deriving benefits from stressful events: The role of engagement in meaningful work and hardiness," Journal of Occupational Health Psychology, vol. 6, pp. 53-63, 2001.

[29] C. Maslach, W. B. Schaufeli, and M. P. Leiter, "Job burnout," Annual Review of Psychology, vol. 52, pp. 397-422, 2001.

[30] L. Hatcher, A step-by-step Approach to Using the SAS System for Factor Analysis and Structural Equation Modeling, Carry, N.C.: SAS Institute, Inc., 1994.

[31] J. Pallant, SPSS Survival Manual: A Step by Step Guide to Data Analysis Using SPSS Version 12, 2nd ed. Buckingham: Open University Press, 2005

[32] R. M. Baron and D. A. Kenny, "The moderator-mediator variable distinction in social psychological research: Conceptual, strategic, and statistical considerations," Journal of Personality and Social Psychology, vol. 51, pp. 1173-1182, 1986.

[33] A. F. Hayes, "Beyond Baron and Kenny: Statistical Mediation Analysis in the New Millennium," Communication Monographs, vol. 76, No. 4, pp. 408-420, 2009.

[34] D. P. MacKinnon, Introduction to Statistical Mediation Analysis, Mahwah, NJ: Lawrence Erlbaum Associates, Inc., 2008.

[35] D. P. MacKinnon, C. M. Lockwood, and J. Williams, "Confidence limits for the indirect effect: Distribution of the product and resampling methods," Multivariate Behavioral Research, vol. 39, pp. 99-128, 2004.

[36] J. Williams and D. P. MacKinnon, "Resampling and distribution of the product methods for testing indirect effects in complex models," Structural Equation Modeling, vol. 15, pp. 23-51, 2008.

[37] J. K. Preacher and A. F. Hayes, "SPSS and SAS procedures for estimating indirect effects in simple mediation models," Behavior Research Methods, Instruments, \& Computers, vol. 36, no. 4, pp. 17-731, 2004.

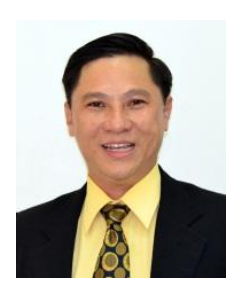

Mai Ngoc Khuong is a lecturer and researcher of School of Business Administration, International University, Vietnam National University, Ho Chi Minh City. He has a bachelor degree in tourism and hospitality management, a master of science degree in leisure, tourism and environment at Wageningen University, The Netherlands, and a $\mathrm{PhD}$ degree in development management at School of Public Administration of the National Institute of Development Administration (NIDA), Bangkok, Thailand.

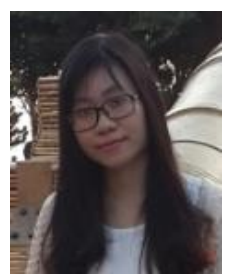

Do Thi Thuy Dung was born on August 14, 1993 in Vung Tau City. She is an undergraduate student of School of Business Administration of International University, Vietnam National University, Ho Chi Minh City. Her major is international business. 